\title{
Peningkatan Keaktifan dan Hasil Belajar Siswa Dengan Metode Stad (Student Team Achievement Divisions) Pada Mata Pelajaran Vegetatif Di Kelas X ATPH SMK Negeri 5 Jeneponto
}

\author{
Nur Amin Mangka, Program Studi Pendidikan Teknologi Pertanian Fakultas Teknik, \\ Universitas Negeri Makassar. Email: chockmt32@gmail.com \\ Andi Sukainah, Program Studi Pendidikan Teknologi Pertanian Fakultas Teknik, Universitas \\ Negeri Makassar. Email: andisukainah@yahoo.com \\ Nurmila, Program Studi Pendidikan Teknologi Pertanian Fakultas Teknik, Universitas \\ Negeri Makassar. Email: nurmilab@unm.ac.id
}

\begin{abstract}
Abstrak
Penelitian ini adalah Penelitian Tindakan Kelas yang bertujuan untuk mengetahui peningkatan aktivitas dan hasil belajar siswa kelas ATPH X vegetatif SMK Negeri 5 Jeneponto melalui model pembelajaran kooperatif tipe STAD. Subjek penelitian ini terdiri dari 23 siswa kelas X ATPH, menggunakan teknik pengumpulan data observasi dan tes pada akhir setiap siklus sesuai dengan materi yang diajarkan. Prosedur penelitian meliputi tahapan (a) perencanaan, (b) implementasi, (c) observasi, dan (d) refleksi. Hasil penelitian menunjukkan bahwa penerapan model pembelajaran kooperatif STAD (Student team achievement divisons) dapat meningkatkan aktivitas siswa dan hasil belajar. Hal ini dapat dilihat pada kegiatan Siklus I dan Siklus II dan hasil belajar siswa meningkat.
\end{abstract}

Kata kunci: Penelitian Tindakan Kelas, Kegiatan Belajar, Hasil Belajar, STAD.

\section{Abstract}

This research is Classroom Action Research which aims to determine the increase in activity and learning outcomes of vegetative ATPH X class students of SMK Negeri 5 Jeneponto through the STAD type cooperative learning model. The subject of this study consisted of 23 students of class $X$ ATPH, using the technique of collecting observation and test data at the end of each cycle according to the material being taught. Research procedures include stages (a) planning, (b) implementation, (c) observation, and (d) reflection. The results of the study indicate that the application of the STAD cooperative learning model (Student Team Achievement Division) can improve student activity and learning outcomes. This can be seen in Cycle I and Cycle II activities and student learning outcomes increase.

Keywords: Classroom Action Research, Learning Activities, Learning Outcomes, STAD.

\section{Latar Belakang}

Memasuki era globalisasi yang ditandai dengan cepatnya arus informasi di berbagai aspek dan sistem kehidupan manusia, dunia pendidikan di Indonesia dihadapkan pada berbagai tantangan. Di antaranya tantangan sebagai akibat krisis ekonomi, dunia pendidikan dituntut untuk dapat mempertahankan hasil-hasil pembangunan pendidikan yang telah dicapai, untuk mengantisipasi era globalisasi, dunia pendidikan dituntut untuk mempersiapkan sumber daya manusia yang kompeten agar mampu bersaing dalam pasar global, dengan diberlakukannya otonomi daerah kebijaksanaan pendidikan perlu memperhatikan keberagaman atau keadaan daerah, peserta didik, partisipasi peserta didik, dan partisipasi masyarakat. Hal Ini Tertuang Dalam Undang-Undang Republik Indonesia Tentang Sistem Pendidikan Nasional BAB 1 Pasal 1 Ayat 1 Yaitu: 
Pendidikan adalah usaha sadar dan terencana untuk mewujudkan suasana belajar dan proses pembelajaran agar peserta didik secara aktif mengembangkan potensi dirinya untuk memiliki potensi spiritual, keagamaan, pengendalian diri, kepribadian, kecerdasan, ahlak mulia serta keterampilan yang diperlukan dirinya, masyarakat, bangsa dan negara.

Pendidikan sangat berperan penting dalam menciptakan manusia yang berkualitas dan berpotensi, melalui pendidikan akan terjadi pendewasaan diri sehingga didalam proses pengambilan keputusan selalu disertai dengan rasa tanggung jawab yang besar. Menurut Evans dalam Djojonegro (1999) mendefinisikan bahwa pendidikan kejuruan adalah bagian dari sistem pendidikan yang mempersiapakan seseorang agar lebih mampu bekerja pada satu kelompok pekerjaan atau satu bidang pekerjaan dari pada bidang-bidang pekerjaan lainnya.

Upaya dalam meningkatkan kualitas pendidikan, maka peneliti mengemukakan model pembelajaran yang akan diterapkan pada sebuah Sekolah Menengah Kejuruan (SMK), sehingga mampu mengubah pola belajar siswa yang semula menggunakan metode konvensional menjadi sebuah pembelajaran yang mampu menarik minat belajar siswa, agar mampu memberikan hasil yang terbaik. Penelitian tindakan kelas ini bertujuan untuk mengubah pola belajar siswa, yang awalnya hanya dilakukan dengan pemberian materi (metode ceramah) yang membuat siswa seolah-olah berkhayal dalam penerimaan materi yang diberikan berubah menjadi pola belajar aktif (student centered). Sehingga untuk mengatasi permasalahan tersebut guru dapat menggunakan model pengajaran yang lebih mengaktifkan siswa dalam proses belajar mengajar. Pembelajaran yang berkualitas melibatkan seluruh komponen utama proses belajar mengajar yaitu guru, peserta didik, materi, dan fasilitas pendudkung lainnya (Ariana, Dkk. 2018).

Model pembelajaran dengan menggunakan metode STAD (Student Team Achievment Divisions) memiliki kelebihan dan kekurangan, sehingga di dalam memilih model pembelajaran guru dituntut untuk memilih dan menggunakan model yang tepat dan menyenangkan siswa. Menurut Saraswati, dkk. (2018), pembelajaran merupakan aktivitas yang terdiri atas komponen-komponen yang bersifat sistematik. Kurang tanggapnya guru memilih model dalam pembelajaran dapat mengakibatkan siswa kurang mengerti dan kurang memperhatikan bahan pelajaran yang diberikan. Pemilihan model pengajaran haruslah berorientasi pada siswa yang dapat melibatkan keaktifan siswa dalam proses pembelajaran. Keaktifan siswa dalam pembelajaran dapat mengembangkan potensi-potensi belajar siswa secara optimal baik yang bersifat fisik, mental, emosional maupun intelektualnya, sehingga tujuan pembelajaran yang diinginkan dapat tercapai secara optimal.

Berdasarkan pengamatan dan observasi awal yang telah dilakukan terhadap siswa kelas X ATPH SMK Negeri 5 Jeneponto tentang pembelajaran vegetatif ditemukan berbagai permasalahan yang muncul dalam kegiatan proses belajar mengajar khususnya pada mata pelajaran vegetatif. Pada proses pembelajaran vegetatif di kelas terjadi interaksi aktif positif antara peserta didik dengan guru, tetapi sebaliknya interaksi antar peserta didik dengan peserta didik lain jarang terjadi. Peserta didik terlihat kurang terampil menjawab pertanyaan ataupun bertanya tentang materi yang diajarkan. Peserta didik tidak antusias menerima pembelajaran, hal ini terlihat masih banyaknya peserta didik yang berinteraksi dengan peserta didik lainnya yang membahas diluar materi yang diajar serta siswa masih kurang aktif dan kurang bersemangat dalam mengikuti kegiatan pembelajaran, siswa cenderung belajar 
sendiri-sendiri dengan tidak membentuk kelompok belajar, dan siswa lebih banyak bermain dan berbicara dengan teman ketika pembelajaran sedang berlangsung sehingga kelas menjadi gaduh dan pembelajaran yang disampaikan oleh guru menjadi tidak efektif serta dalam proses pembelajaran di kelas guru hanya transformasi pengetahuan kepada peserta didik tanpa melibatkan siswa dalam pencariannya, sehingga siswa hanya mencatat, dan menjadi objek yang pasif dalam proses pembelajaran. Sedangkan berdasarkan hasil wawancara dengan guru kelas ATPH menyatakan bahwa hasil belajar siswa masih rendah dilihat dari kuantitatif rata-rata hasil pembelajaran siswa kelas X ATPH hanya 65, sehingga belum mencapai kriteria ketuntasan minimum (KKM) yang diterapkan pada mata pelajaran vegetatif sebesar 70 , dan secara tidak langsung siswa belum mencapai kriteria ketuntasan secara klasikal sebesar $75 \%$ dari jumlah keseluruhan siswa yang tuntas. (Sumber: SMK Negeri 5 Jeneponto)

\section{Berdasarkan pertimbangan} tersebut, maka diperlukan model pembelajaran yang mampu meningkatkan peran siswa secara menyeluruh untuk meningkatkan hasil belajar vegetatif, menurut Aprilia, dkk. (2018). Dalam proses pembelajaran diperlukan penerapan model pembelajaran yang mampu mendorong siswa untuk aktif dan dapat meningkatkan hasil belajar pada siswa. Salah satunya dengan menggunakan pembelajaran kooperatif tipe STAD. Pembelajaran kooperatif ini mencakup suatu kelompok kecil siswa yang bekerja sebagai sebuah tim untuk menyelesaikan suatu masalah, menyelesaikan suatu tugas atau mengerjakan sesuatu untuk mencapai tujuan bersama lainnya. Pembelajaran ini menekankan pada aspek sosial antar siswa dalam kelompok yang heterogen. STAD merupakan salah satu tipe pembelajaran kooperatif yang berguna untuk mencapai tujuan pembelajaran dan membuat peserta didik lebih aktif dengan memadukan penggunaan metode ceramah, questioning dan diskusi. Penerapan model pembelajaran kooperatif tipe STAD pada mata pelajaran Vegetatif juga diharapkan mampu meningkatkan keaktifan dan hasil belajar siswa. Pada proses pembelajaran dengan model pembelajaran kooperatif tipe STAD, peserta didik akan melalui beberapa tahapan yaitu penyajian materi, pembagian kelompok, diskusi, tes individual, pemberian penghargaan kelompok, dan evaluasi kegiatan belajar mengajar serta menyimpulkan materi pembelajaran. Penerapan strategi pembelajaran STAD, dapat memberikan kontribusi positif dalam mencapai tujuan pembelajaran dan meningkatkan keaktifan peserta didik dalam belajar.

Dengan pola pemikiran yang demikian. Adapun judul penelitian yang akan peneliti angkat ialah "Peningkatan Keaktifan Dan Hasil Belajar Siswa Dengan Metode STAD (Student Team Achievement Divisions) Pada Mata Pelajaran Vegetatif Di Kelas X ATPH SMK Negeri 5 Jeneponto".

\section{Tujuan Penelitian}

Berdasarkan rumusan malasah di atas maka tujuan yang ingin dicapai dalam penelitian ini adalah Untuk mengetahui peningkatan keaktifan dan hasil belajar siswa pada mata pelajaran vegetatif kelas $X$ ATPH SMK Negeri 5 Jeneponto melalui model pembelajaran kooperatif tipe STAD (Student Team Achievement Divisions).

\section{Bahan dan Metode}

Bentuk penelitian yang akan digunakan adalah penelitian tindakan kelas (Classroom Action Research), yang dilakukan secara kolaboratif, Penelitian tindakan kelas ini memiliki tahapantahapan yang meliputi: menyusun rancangan tindakan (planning), pelaksanaan tindakan (action), pengamatan (observing), dan evaluasi serta refleksi (reflecting) secara berulang sesuai dengan siklus pembelajaran. 
Lokasi Penelitian ini dilaksanakan di SMK Negeri 5 Jeneponto bertempat di Kel. Ta'bing Tinggia, Kec. Bangkala Barat, Kab. Jeneponto. Waktu penelitian dilaksanakan pada semester genap tahun ajaran 2017/2018 sesuai jadwal penelitian.

Subjek penelitian adalah siswa kelas X ATPH SMK Negeri 5 Jeneponto semester genap tahun ajaran 2017 yang berjumlah 23 siswa. Dengan jumlah siswa laki-laki sebanyak 10 siswa dan jumlah siswa perempuan sebanyak 13 siswa.

Ukuran dari indikator keberhasilan hasil belajar peserta didik adalah tes hasil belajar peserta didik yang sudah menunjukkan peningkatan ketuntasan belajar. Peserta didik dikatakan tuntas belajar apabila kriteria ketuntasan minimal (KKM) yang harus dipenuhi oleh seorang peserta didik adalah nilai $\geq 75$ maka peserta didik yang bersangkutan mencapai ketuntasan individu, dan tuntas secara klasikal 85\%.

\section{Hasil dan Pembahasan}

Hasil dan analisis data penelitian ini dibuat berdasarkan data yang diperoleh dari kegiatan penelitian tentang prestasibelajar siswa pada mata pelajaran vegetatif

melalui model pembelajaran kooperatif STAD (student team achievement divions) yang dilaksanakan di SMK Negeri 5 Jeneponto. Pelaksanaan penelitian ini dilakukan selama 2 siklus. Adapun yang dianalisis adalah hasil tes awal (pretest), tes siklus I dan siklus II, serta data tambahan berupa perubahan sikap siswa yang diambil dari hasil pengamatan terhadap siswa selama penelitian berlangsung. Hasil dan pembahasan yang diperoleh dari dua siklus selama penelitian ini adalah sebagai berikut:

\section{Tes Awal (pretest)}

Tabel 1. Distribusi frekuensi ketuntasan belajar siswa pada tes awal

\begin{tabular}{cccc}
\hline Skor & Frekuensi & Persentase $(\%)$ & Kategori \\
\hline $0-74$ & 23 & 100 & Tidak tuntas \\
$75-100$ & 0 & 0 & Tuntas \\
Jumlah & 23 & 100 & \\
\hline
\end{tabular}

Sumber: : Hasil analisis data penelitian

Pada tabel 1, menunjukkan bahwa pada tes awal persentase ketuntasan belajar siswa sebesar $0 \%$ yaitu 23 siswa belum ada dalam kategori tuntas, sedangkan $100 \%$ yaitu 23 siswa termasuk dalam kategori tidak tuntas. Hal ini menunjukkan bahwa dari 23 jumlah siswa belum ada siswa yang tuntas hasil belajarnya dan masih sangat memerlukan perbaikan pada pembelajaran siklus I.

\section{Siklus I}

Tabel 2. Distribusi ketuntasan belajar kompetensi kejuruanSiswa kelas X ATPH SMK Negeri 5 Jeneponto pada siklus I

\begin{tabular}{cccc}
\hline Skor & Frekuensi & Persentase $(\%)$ & Kategori \\
\hline $0-74$ & 16 & 69.57 & Tidak tuntas \\
$75-100$ & 7 & 30.43 & Tuntas \\
Jumlah & 23 & 100 & \\
\hline
\end{tabular}

Sumber: Hasil analisis data penelitian 
Berdasarkan Tabel 2, terlihat bahwa hasil ketuntasan belajar pada siklus I sebesar $30.53 \%$ atau 7 siswa dari 23 siswa berada dalam kategori tuntas dan $69.57 \%$ atau 16 siswa dari 23 siswa berada dalam kategori tidak tuntas. Hal ini berarti bahwa terdapat 16 siswa yang perlu perbaikan karena belum mencapai kriteria ketuntasan belajar. Hal ini dinyatakan karena berdasarkan kriteria hasil belajar mengenai ketuntasan kelas secara klasikal yaitu $75 \%$ dari jumlah siswa yang tuntas, data hasil penelitian dari siklus I dianggap belum tuntas karena yang tuntas sangat kurang hanya $30.43 \%$.

\section{Keaktifan Siswa}

Data keaktifan siswa diperoleh melalui lembar observasi selama proses belajar berlangsung setiap pertemuan yang dilakukan oleh observator. Keaktifan siswa yang diamati selama proses belajar sebanyak enam komponen. Distribusi Keaktifan siswa dapat dilihat pada Tabel 3.

Tabel 3. Distribusi Frekuensi Observasi Keaktifan Siswa pada Siklus I

\begin{tabular}{|c|c|c|c|c|c|c|}
\hline \multirow{2}{*}{ No } & \multirow{2}{*}{ Komponen yang diamati } & \multicolumn{4}{|c|}{ Pertemuan } & \multirow{2}{*}{$\begin{array}{c}\text { rata-rata } \\
(\%)\end{array}$} \\
\hline & & $\mathrm{I}$ & II & III & IV & \\
\hline 1 & Kehadiran siswa & 20 & 20 & 20 & 23 & 90.2 \\
\hline 2 & $\begin{array}{l}\text { Siswa yang aktif dalam } \\
\text { kegiatan kelompok }\end{array}$ & 6 & 12 & 18 & & 52.2 \\
\hline 3 & $\begin{array}{l}\text { Menjelaskan permasalahan } \\
\text { (problem solving) }\end{array}$ & 4 & 5 & 6 & & 21.7 \\
\hline 4 & $\begin{array}{l}\text { Siswa yang bertanya tentang } \\
\text { materi yang belum dimengerti }\end{array}$ & 5 & 5 & 4 & & 20.3 \\
\hline 5 & $\begin{array}{l}\text { Siswa yang meminta } \\
\text { bimbingan kepada guru dalam } \\
\text { proses diskusi kelompok }\end{array}$ & 3 & 5 & 5 & 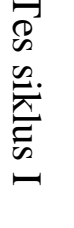 & 18.8 \\
\hline 6 & $\begin{array}{l}\text { Siswa yang melakukan } \\
\text { kegiatan lain baik dalam proses } \\
\text { pemberian materi pelajaran } \\
\text { maupun pada saat diskusi } \\
\text { kelompok }\end{array}$ & 6 & 4 & 5 & & 21.7 \\
\hline
\end{tabular}

Sumber: Hasil analisis data penelitian

\section{Siklus II}

Tabel 4. Distribusi ketuntasan belajar kompetensi kejuruan Siswa kelas X ATPH SMK Negeri 5 Jeneponto pada siklus II

\begin{tabular}{cccc}
\hline Skor & Frekuensi & Persentase $(\%)$ & Kategori \\
\hline $0-74$ & 2 & 8.70 & Tidak tuntas \\
$75-100$ & 21 & 91.30 & Tuntas \\
Jumlah & 23 & 100 & \\
\hline
\end{tabular}

Sumber: Hasil analisis data penelitian. 
Berdasarkan Tabel di atas, terlihat bahwa hasil ketuntasan belajar pada siklus II sebesar $91,30 \%$ atau 21 siswa dari 23 siswa berada dalam kategori tuntas dan $8.70 \%$ atau 2 siswa dari 23 siswa berada dalam kategori tidak tuntas. Hal ini berarti bahwa terdapat 2 siswa yang perlu perbaikan karena belum mencapai kriteria ketuntasan belajar. Hal ini berarti bahwa penelitian ini tidak perlu dilanjutkan pada siklus berikutnya karena berdasarkan tujuan yang ingin dicapai, yaitu terjadi peningkatan hasil belajar yang dinyatakan berdasarkan kriteria hasil belajar mengenai ketuntasan kelas secara klasikal, yaitu $\geq 75$
$\%$ dari jumlah siswa yang tuntas, data hasil penelitian pada siklus II di atas dianggap tuntas dikarenakan siswa yang sudah tuntas telah mencapai $91.30 \%$

\section{Keaktifan siswa}

Data keaktifan siswa diperoleh melalui lembar observasi selama proses belajar berlangsung setiap pertemuan yang dilakukan oleh observator. Keaktifan siswa yang diamati selama proses belajar sebanyak enam komponen. Distribusi keaktifan siswa dapat dilihat pada Tabel 5.

Tabel 5. Distribusi Frekuensi Observasi Keaktifan Siswa pada Siklus II

\begin{tabular}{|c|c|c|c|c|c|c|}
\hline \multirow{2}{*}{ No } & \multirow{2}{*}{ Komponen yang diamati } & \multicolumn{4}{|c|}{ Pertemuan } & \multirow{2}{*}{$\begin{array}{c}\text { rata-rata } \\
(\%)\end{array}$} \\
\hline & & $\mathrm{I}$ & II & III & IV & \\
\hline 1 & Kehadiran siswa & 22 & 21 & 21 & 23 & 94.5 \\
\hline 2 & $\begin{array}{l}\text { Siswa yang aktif dalam } \\
\text { kegiatan kelompok }\end{array}$ & 13 & 15 & 21 & & 71 \\
\hline 3 & $\begin{array}{l}\text { Menjelaskan permasalahan } \\
\text { (problem solving) }\end{array}$ & 7 & 8 & 7 & & 31.8 \\
\hline 4 & $\begin{array}{l}\text { Siswa yang bertanya tentang } \\
\text { materi yang belum dimengerti }\end{array}$ & 10 & 10 & 6 & $\overrightarrow{8}$ & 37.6 \\
\hline 5 & $\begin{array}{l}\text { Siswa yang meminta } \\
\text { bimbingan kepada guru dalam } \\
\text { proses diskusi kelompok }\end{array}$ & 7 & 8 & 9 & 离. & 34.7 \\
\hline 6 & $\begin{array}{l}\text { Siswa yang melakukan } \\
\text { kegiatan lain baik dalam proses } \\
\text { pemberian materi pelajaran } \\
\text { maupun pada saat diskusi } \\
\text { kelompok }\end{array}$ & 2 & 4 & 2 & & 11.5 \\
\hline
\end{tabular}

Sumber: Hasil analisis data penelitian.

\section{Pembahasan}

Hasil observasi yang dilakukan selama dua siklus dengan menerapkan metode pembelajaran kooperatif tipe STAD (Student Team Achievement Divisions) pada mata pelajaran pembiakan tanaman secara vegetatif diperoleh peningkatan hasil belajar siswa.
Berdasarkan tes siklus I persentase ketuntasan siswa sebesar $30.43 \%$ atau 7 siswa dari 23 siswa. Hal ini belum mencapai KKM mata pelajaran pembiakan tanaman secara vegetatif sebesar 75 dan belum mencapai kriteria ketuntasan klasikal $85 \%$ dari jumlah siswa yang tuntas sehingga diperlukan evaluasi kekurangan yang terdapat pada siklus I 
untuk selanjutnya dilanjutkan pada siklus II. Pada siklus II presentase ketuntasan siswa meningkat sebesar $60,73 \%$ sehingga mencapai ketuntasan pada siklus II dengan persentase ketuntasan $91,30 \%$ atau 21 siswa dari 23 siswa. Hal ini menunjukkan bahwa peningkatan hasil belajar siswa telah mencapai KKM mata pelajaran pembiakan tanaman secara vegetatif sebesar 75 dan telah mencapai kriteria ketuntasan klasikal 85\% dari jumlah siswa yang tuntas dan telah memenuhi indikator keberhasilan yang telah ditetapkan oleh Departemen Pendidikan Nasional.

\section{Simpulan}

Berdasarkan hasil analisis data dan pembahasan, maka dapat disimpulkan bahwa penerapan model pembelajaran STAD (student team achievement divisions) dapat meningkatkan pretasi belajar siswa pada mata pelajaran Kompetensi Kejuruan di kelas X ATPH SMK Negeri 5 Jeneponto, hal ini dapat dilihat dari ketuntasan secara klasikal pada tes awal $0 \%$ siswa tidak tuntas, pada siklus I terjadi peningkatan sebesar $30.43 \%$ sehingga ketuntasan secara klasikal menjadi $30.43 \%$ dan pada siklus II terjadi peningkatan hasil belajar sebesar $60.87 \%$ sehingga ketuntasan secara klasikal menjadi $91.30 \%$.

\section{Daftar Pustaka}

Aprilia. A. T., M. Yahya., M. W. Caronge. 2018. Penerapan Model
Pembelajaran Kooperatif Tipe TGT Untuk Meningktakan Hasil Belajar Membiakkan Tanamanan Secara Vegetatif Pada Siswa Kelas X SMK Negeri 3 Takalar. Jurnal Pendidikan Teknologi Pertanian, Vol. 4 (2018) : $73-81$

Ariana. I., M. W. Caronge., Lahming. 2018. Peningkatan Prestasi Belajar Pada Mata Pelajaran Alat Dan Mesin Pertanian Melalui Model Pembelajaran Terpadu Tipe Connected Pada Siswa Kelas XII ATPH SMK Negeri 2 Bulukumba. Jurnal Pendidikan Teknologi Pertanian, Vol. 4 (2018) : 1 - 12

Departemen Pendidikan Nasional 2006. Undang-Undang No 20 Tahun 2003 Tentang Sistem Pendidikan Nasional. Bandung : Fokusmedia

Evans Dalam Djojonegro. 1999. Pendidikan Kejuruan. Jakarta

Saraswati., M. Rais., Lahming. 2018. Penerapan Model Pembelajaran Kooperatif Tipe Two Stay Two Stray (TSTS) Untuk Meningkatkan Prestasi Belajar Pada Mata Pelajaran Teknologi Pengolahan Hasil Pertanian (TPHP) Kelas X SMK Negeri 3 Takalar. Jurnal Pendidikan Teknologi Pertanian Volume 4 Oktober Suplemen (2018) : S184 S195 